\title{
Timeshift: technologies of reproduction and intellectual property
}

\author{
John Frow
}

\begin{abstract}
In recent years two factors have significantly affected the underlying conditions for the public circulation of ideas and information. On the one hand, the development of technologies for the electronic reproduction and dissemination of information has in principle made information limitlessly available; on the other hand, the process of legal regulation has, in all Western countries, constructed or affirmed property rights restricting and channelling the use of information. This paper analyses one of the most important recent American cases in intellectual property law, the 1984 Supreme Court majority and minority decisions in Sony vs Universal City Studios. It argues that, in allowing home video recording of off-air programmes and extending or at least upholding the doctrine of fair use, the Court's decision nevertheless fails to challenge the philosophical contradictions in intellectual property doctrine which have allowed the progressive encroachment of private property rights on the public domain.
\end{abstract}

In a time of rapid and sustained technological change there is an obvious temptation to attribute efficient causal power to technology. It perhaps bears repeating that technology is never a historical force in its own right; it is developed within, it is constrained and shaped by and it has effects upon particular sets of social relations. In this paper I look at the disruptive force of a newly devised technology of reproduction upon the legal relations which constituted in part its conditions of existence. The paper is concerned with the law and with the maintenance of legal authority, rather than directly with the technology; but neither the law nor the new technology (with all its financial, industrial and cultural ramifications) can be understood in abstraction from each other.

The technology is that of the video-cassette recorder, developed in various stages by American and Japanese companies but making its most dramatic impact on the market in 1976 in the form of Sony's Betamax system (for the 
history, cf. Lardner 1987; Marlow and Secunda 1991). The VCR (or VTR) was one of a number of new systems for the reproduction and manipulation of information to appear in the 1960s and 1970s; others included the audio-cassette recorder, the photocopier and the personal computer. Taken together, they represented a major threat to the private ownership of intellectual property. All of them facilitated the transfer of elaborated information from a locked and singular repository (the record, the unique broadcast of a television programme, the self-contained and copy-protected software program) to a site of repetition and uncontrolled use. All of them thereby threatened the financial rewards derived from the careful control of an original text.

Much of the most interesting recent work on intellectual property, both in legal studies and in media and cultural studies, has focused on the contradiction between the possibilities opened up by these technologies of reproduction and the regulation and restriction of reproducibility by means of the differential allocation of rights. Celia Lury, for example, argues that 'it was through the constitution of cultural works as intellectual property, and the allocation of limited rights of reproduction, that the potential instability inherent in reproduction made possible by modern technologies of culture was contained' (Lury 1993: 23). The copyright (or the droit d'auteur in some European systems) is the most powerful of these rights as far as cultural works are concerned, although both Lury (1993) and Gaines (1991) note a gradual move towards trademark protection or 'branding' in systems of mass-cultural production. Copyright, which partially derives from and in turn helps to sustain the post-Romantic author function, ${ }^{1}$ balances a limited right to copy against a limited monopoly right to exploit a protected work (cf. Frow 1988); this right of exploitation is, as a corollary, a right to restrict the making of copies of that work.

One of the key American judicial responses to the challenge posed by the new reproductive technologies was the 1984 United States Supreme Court decision in Sony Corporation of America v. Universal City Studios, Inc. ${ }^{2}$ The case was originally brought in 1976 in the United States District Court for the Central District of California by Universal City Studios and Walt Disney Productions against Sony Corporation and Sony Corporation of America, the Japanese manufacturer and American distributor respectively of the Betamax VTR. It was alleged that television programme copyrights held by the two studios were being infringed by home recording, and that Sony was guilty of contributing to this breach of copyright (it was liable for "contributory infringement'). Less explicitly, but perhaps more importantly, what was at stake was the ability of the producers and broadcasters to reach a targeted audience and to protect advertising revenue through the fixing of a linear, non-manipulable schedule. The brief history of the case is that the District Court found in favour of Sony; the Ninth Circuit Court of Appeals reversed and found Sony liable for contributory infringement; and, finally, the 
Supreme Court upheld the initial judgment, finding Sony not liable by a bare majority of five to four.

The case is exemplary in its interweaving of quite specifically legal discourses with an economic discourse that attempts to clarify the paradox of a restriction of public access (a deliberate production of scarcity) that will, through the mechanism of incentive, eventually increase public access and promote abundance. Both the 'liberal' and the 'conservative' discourses at play in this case rely upon the categories of the market, of limited regulation and of individual rather than corporate property rights. They differ in the extent to which they are prepared to limit the 'limited monopoly' given to copyright holders.

In what follows I shall try to summarize the substantive arguments on both sides, but I shall pay particular attention to the formal processes of citation and authorization through which these arguments are constructed. The discursive authority with which the two groups of judges try to endow their cases is built up through three types of procedure: first, through an appeal to authoritative texts, including the Constitution, the statute and its legislative history (including the House and Senate reports, exchanges in the House and various preparatory materials); second, through a construction of verifications from various 'lower' texts: from case history, from the findings of the District Court and the Court of Appeals, from testimony in those courts, from patent doctrine and from academic articles; and, third, through the rejection of opposing texts, primarily each other's opinions - but for the sake of propriety this is mediated by the decisions of the District Court and the Court of Appeals.

These procedures correspond to the traditional hierarchy of juridical discourses. I want to suggest, however, that such a conception of a pre-given hierarchical structure is untenable because it does not correspond to the real distribution of discursive authority (this is created, rather, in the constant process of incorporation, citation and commentary on other discourses of whatever 'level'). In any case, the positivist appeal to a source of law, a final discursive authority, is based in a certain suppression of paradox. At its summit the rules of law derive from an extra-legal vanishing point: the point at which a sovereign or a legislature must formulate the rule of recognition that specifies the validity of its own rule-making procedures. This validity is grounded, therefore, in an endlessly self-reflexive spiral; and, in turn, the recognition rule could be confirmed only by courts established by the rule. The only 'final' ground of a legal system is an extra-legal fiat (historically an act of force which the law itself then legitimizes). ${ }^{3}$

The opinion of 'the Court' is made up of an introduction and five sections. The introduction summarizes the facts of the case and the decisions taken, with particular reference to the difference of opinion between the District Court and the Court of Appeals over the significance for copyright protection of timeshifting - that is, the recording of a programme in order to be able to play it back and watch it at a more convenient time. In Section I, the 
Court quotes extensively from the District Court's decision, which emphasized

that the material was broadcast free to the public at large, the noncommercial character of the use, and the private character of the activity conducted entirely within the home. Moreover, the court found that the purpose of this use served the public interest in increasing access to television programming, an interest that is consistent with the First Amendment policy of providing the fullest possible access to information through the public airwaves. Columbia Broadcasting System, Inc. v Democratic National Committee, 412 US 94, 10236 L Ed 2d 772, 93 S Ct 2080.' (582/425)

The District Court found that home copying constituted fair use " "because there is no accompanying reduction in the market for 'plaintiff's original work'" ' $(582 / 426)$ (this is the chief of the four criteria that the Copyright Act sets out for fair use); and it found Sony not liable as a contributory infringer, both because of a lack of good precedent and because it was unwilling to expand the theory of contribution to cover this case (ibid.).

In this summary of the District Court's decision, the questions involved are tested against the Constitution, the statute, copyright doctrine and particular case-law. The summary of the Court of Appeal's decision that follows is restricted to its findings of law: namely, that home-copying cannot be considered fair use because it is not a 'productive use'; and that it would negatively affect the potential market value of copyrighted works.

The second section of the Supreme Court's opinion begins by quoting the Constitutional provision that Congress shall establish exclusive rights in 'Writings and Discoveries', and immediately defines these rights as being 'neither unlimited nor primarily designed to provide a special private benefit'; they yield only 'a limited monopoly' (584/429). Copyright law, that is to say, has to do with a difficult balance, between 'the interests of authors and inventors in the control and exploitation of their writings and discoveries on the one hand, and society's competing interest in the free flow of ideas, information, and commerce on the other hand' (ibid.).

One thread running through the history of copyright law is its sensitivity to technological change. A footnote cites some of the challenges to interpretation of the law posed by piano players and perforated music rolls, by photocopying machines, by cable television and by record piracy; and a further note cites an academic text on the relation between copyright protection and the printing press.

Another thread has to do with what the Court describes as 'the judiciary's reluctance to expand the protections afforded by the copyright without explicit legislative guidance' $(585 / 431)$. Citing a number of cases by way of exemplification (this massing of precedents has the effect of at once invoking and constructing the solidity of an immutable tradition), the Court continues:

Sound policy, as well as history, supports our consistent deference to Congress when major technological innovations alter the market for 
copyrighted materials. Congress has the constitutional authority and the institutional ability to accommodate fully the varied permutations of competing interests that are inevitably implicated by such new technology. (ibid.)

Both reason and history, both the authority and the power of Congress, set a limit to the interpretative freedom of the Court - in particular when it is a question of 'construing the scope of rights created by a legislative enactment which never contemplated such a calculus of interests' (586/431).

I shall return later to the question of the relation between interpretation, rights and the 'calculus of interests'. Here, the espousal of circumspection announces the literal inapplicability of the statute. The Court cites Justice Stewart's guidelines on the interpretation of copyright law, to the effect that " "when technological change has rendered its literal terms ambiguous, the Copyright Act must be construed in light of [the] basic purpose"' (586/432) of the Constitution: that is, to subordinate the copyright holder's statutory monopoly to the broader public interest in creative work. In opening up the whole question of ambiguity, the argument to deference thus, in the most 'circumspect' language, makes clear its interpretative consequences: the necessity for the Court to intervene in the political calculus of private and public benefits.

The core of the majority judgment lies in the establishment of a distinction between infringing and non-infringing uses of a copyrighted work by reference to the doctrine of fair use, which is the main limitation on the five specific exclusive rights conferred by the Copyright Act. This doctrine is in its origins very much a piece of judge-made law. There was no such provision in the 1909 Copyright Act, and indeed this Act was so comprehensive as to be applicable to 'virtually all potential interactions with a copyrighted work' (596/447, n.29). The Court notes, however, in a remarkable comment on the politics of interpretation, that 'the statute was never so construed. The courts simply refused to read the statute literally in every situation' (ibid.). It was in the space of this refusal that the fair use doctrine was elaborated; and the doctrine was then confirmed by being incorporated - explicitly as a restatement of the doctrine - into the 1976 amendment to the Act (ibid., citing the HR Rep. No. 94-1476, p. 66 [1976]).

The essential point about the doctrine is its lack of content, and so the interpretative latitude it allows to, and indeed imposes upon, the judiciary. It does specify certain general types of exempt use, including use 'for purposes such as criticism, comment, news reporting, teaching (including multiple copies for classroom use), scholarship, or research' (596/448, n.30, citing 17 USC 107), and it lays down four criteria to be taken into account when evaluating the character of a use; but the doctrine is characterized by its openness to 'circumstance', to contingency. Thus the House Report, which the Court invokes in explanation of the 'general intention behind the provision', states:

Although the courts have considered and ruled upon the fair use doctrine over and over again, no real definition of the concept has ever emerged. 
Indeed, since the doctrine is an equitable rule of reason, no generally applicable definition is possible, and each case raising the question must be decided on its own facts. (596/448, n.31, citing HR Rep. No 94-1476, 65-66 [1976])

This encapsulates, in its opposition of the general rule to specific circumstance, a whole empiricist ideology of interpretation; and the report accordingly continues with an explanation that

the endless variety of situations and combinations of circumstances that can [a]rise in particular cases precludes the formulation of exact rules in the statute. The bill endorses the purpose and general scope of the judicial doctrine of fair use, but there is no disposition to freeze the doctrine in the statute, especially during a period of rapid technological change. Beyond a very broad statutory explanation of what fair use is and some of the criteria applicable to it, the courts must be free to adapt the doctrine to particular situations on a case-by-case basis. (ibid.)

The absence of the possibility of strict construction of the statute - indeed, the constraint upon the Court not to be constrained in its application of the doctrine - is central to the majority's use of the fair use clause, as well as to the conflict of interpretation between it and the dissent (indeed, later in this footnote it takes issue briefly with the dissent's use of a sentence from the Senate Report; this is another of those curious chronological ambiguities peculiar to the polytemporality - the 'timeshifting' - of written texts, since the dissenting opinion presumably succeeds the majority opinion, both logically and in time). It is on the basis of the fair use provision, or rather the possibility of fair use, that timeshifting is found not to be an infringement of copyright, and Sony is thus found not to be liable for contributory infringement. The presumption of fairness lies in the fact that timeshifting 'must be characterized as a noncommercial, nonprofit activity' (597/449), and non-commercial uses are presumptively fair.

The dissenting opinion, written by Justice Blackmun, is in many ways a rather bitter attack on the majority option, and it seems to rely all the more heavily for the defeat of its arguments on an elaborate scholarly apparatus. In its introductory paragraph it directly criticizes a number of phrases employed in the majority ruling; and in section I it appeals to Congress to resolve the questions raised by the case and by an 'ill-fitting existing copyright law' (601/457). Section II summarizes the case and gives a slightly different account of the Betamax VTR - this one stressing the existence of two models, one with and one without off-air recording facilities; it also put somewhat more emphasis on the machine's ability to fast-forward through or to erase advertisements, and it stresses the distinction between the functions of 'time-shifting' and of 'library-building' (that is, short-term and long-term storage of the copy).

The next section takes up the definition of the reproduction right given in 
the House and Senate Reports, in order to establish that 'the VTR user produces a material object from which the copyrighted work later can be perceived' $(606 / 464)$ and to conclude that 'neither the statute nor its legislative history suggests any intent to create a general exemption for a single copy made for personal or private use'. Indeed, 'it appears that Congress considered and rejected the very possibility of a special private use exemption' (606/465): the issue was raised in one of the preliminary studies to the legislation, prepared in 1958 by Professor A. Latman, and his suggestion of an exemption was rejected by the Register of Copyrights, who 'opposed the adoption of rules and exemptions to cover specific situations, preferring, instead, to rely on the judge-made fair use doctrine to resolve new problems as they arose' $(607 / 466)$. (This might, of course - counter to the thrust of the dissent's argument - be taken to mean that fair use should in fact cover the exemption which in the legislative history it replaced.) The Register's approach was reflected in the copyright revision bills drafted in 1964, and then in the Act of 1976. And this argument is concluded with the contention that 'when Congress intended special and protective treatment for private use ... it said so explicitly' (608/468) (as in the case of private 'performances', like singing a copyrighted lyric in the shower; indeed, it is only this explicit exemption that makes an ordinary private viewing of a direct television broadcast legal - that is, the fact that the 'performance' of the particular programme takes place within 'the normal circle of a family and its social acquaintances' - 17 USC 101) (609/469, n.18).

The preceding appeal to legislative history has as its goal the construction of a chain of 'intent' - a chain of authorship and influence through the multiple textual process of drafting. From here, the dissenting judges move on to distinguish two possible precedents for an exemption for private copying. Quoting cases, reports to Congress, testimony given at House hearings and academic texts on copyright, they first reject, not merely the precedent set by the permissibility of 'hand copying' of a work, but the certainty of that permissibility itself. They then refuse another implied exemption claimed by the District Court (although the Supreme Court majority expressed no opinion on it) in the legislative history of a 1971 amendment to the 1909 Act, which exempts home sound recordings for noncommercial use. The key passages here are a number of exchanges which took place in the House on the applicability of the amendment to video recording. In each case assurances were given that home video recording is 'something you cannot control'; that it is 'not what this legislation is addressed to'; that ' $\mathrm{I}$ do not see anybody going into anyone's home and preventing this sort of thing'; that the practice of home recording 'is not included in the bill'; and that it 'is considered both presently and under the proposed law to be fair use' $(610 / 471)$.

These statements seem straightforward: I read them as excluding any penalization of people recording at home for private use. The dissent has a more interesting reading, however. It takes these passages, first, as constative statements about the failure of legislative controls (thus 'I do not see anybody 
going into anyone's home...' is read as a description of the unfortunate effects of inadequate provisions for remedy against copyright violation); and, second, as excluding any exemption except for sound recording (since video recording 'is not included in the bill'). In other words, a set of assurances about the limited effects of the bill on private use is read as a description simply of the limits of legislation. If this seems perverse, it is nevertheless exemplary for the way it foregrounds a genuine conflict of interpretations, and one of a familiar textual kind (that is, of a kind common to all interpretation of writing).

Section IV develops an exposition of the concept of fair use in terms of 'productive' use. Each of the recognized fair uses, says the dissent, results 'in some added benefit to the public beyond that produced by the first author's work' (614/478); fair use is permissible, that is, for what a Copyright Office Briefing Paper calls 'socially laudable purposes' (615/478). But, Justice Blackmun adds darkly, 'I am aware of no case in which the reproduction of a copyrighted work for the sole benefit of the user has been held to be fair use' $(615 / 479)$, and there is therefore no justification for the user's being provided with 'a fair use subsidy at the author's expense' $(615 / 480)$.

The opposition of the productive to the unproductive now becomes unmistakably moralistic, and it is a distinctively economic moralism (a moralism of the free market). The District Court had found that " Betamax owners use the copy for the same purpose as the original. They add nothing of their own"' $(615 / 480)$. There is an argument that a fair use exemption would 'increase public access to material broadcast free over the public airwaves'; but this argument 'misconceives the nature of copyright. Copyright gives the author a right to limit or even to cut off access to his work' (a case is cited in support). 'A VTR recording creates no public benefit sufficient to justify limiting this right', and the fact that a copyright owner has licensed a single television performance does not obviate his 'exclusive right to control the performance and the reproduction of his work' (615-616/480).

Now, this relation between the single original performance and subsequent reproductions of it goes to the heart of the problems posed to copyright law by any technology of reproduction (and, more broadly, by what Attali (1985) calls an 'economy of repetition'). In an earlier footnote this opinion had cited the Register of Copyright's view that 'in general the concept of "performance" must be distinguished sharply from the reproduction of copies' $(609 / 469, \mathrm{n} .19)$. The timeshifting of a television programme, however, tends to blur this distinction, since it is a copying done for the sake of a performance: it reproduces the content and the conditions of an 'original' performance, but it is also capable of then being used to multiply this performance. The theoretical problem is precisely, as the District Court says, that 'Betamax owners use the copy for the same purpose as the original' $(615 / 480)$. They may entirely duplicate that use, or they may multiply it through successive performances. This is to say that the copied and timeshifted programme has the ambiguous temporality and effects of 
writing. Whereas the 'original performance' is a one-off event, like speech, the timeshifted text is capable of infinite iteration through multiple contexts and with uncontrollable effects. ${ }^{4}$ In this it resembles - for example - the multiple and at times reversed temporality of the judicial text, and of all the writings of the law.

The major limitation of the reading I have made of Sony is that it addresses only those interdiscursive relations that are explicit. Perhaps of equal interest are those relations which are not controlled by the text, relations which overdetermine it in ways that constitute its unconscious conditions of operation. These are the relations that Pêcheux (1982: 64), following Henry, calls 'preconstruction': relations to a discourse which is absent or elsewhere and which forms the 'unthought' of the text's enunciation; they constitute the limits of the text, the points at which it is inscribed into discourses which are unknown to it, or which are so 'obvious' as to be invisible.

Let me try to isolate two such sets of relations. The first has to do with the question of the role played by social 'interests' in judicial interpretation. Consider the line-up of sponsors of amicus curiae briefs on each side:

- for the petitioners: Viare Publishing, Toshiba, Hitachi, Sears Roebuck, Pfizer, seventeen states of the Union, five major advertising companies, TDK Electronics, the American Library Association, General Electric, Matsushita, NAP Electronics, Panasonic, RCA, JVC, Victor, thirteen consumer associations and Sanyo.

- for the respondents: the Association of American Publishers, the Association of American University Presses, the Committee on Copyright and Literary Property of the Association of the Bar of the City of New York, the Motion Picture Association of America, two writers' guilds, the Screen Actors' Guild, the Directors' Guild, the International Alliance of Theatrical Stage Employees and Moving Picture Machine Operators, the Creators and Distributors of Programs, the Volunteer Lawyers for the Arts, the Recording Industry Association of America, CBS and the National Music Publishers' Association (950-956).

Each of these is a heterogeneous alliance. What they represent is the peculiarly political phenomenon of formations of interest - that is, alliances of quite diverse social groups into a general (but transient) structure of interest. Each side thus represents a massive social pressure, and together they exemplify the social contradictions - the 'calculus of interests' - that the Court must try to reconcile.

Part of the juridical ideology within which the Court works, however, is the claim that questions of law are decided on the basis of purely legal criteria. Thus the Court explicitly rejects any interest or standing of the amici in the case - that is, any consideration of extra-juridical factors:

The stated desires of amici concerning the outcome of this or any litigation are no substitute for a class action, are not evidence in the case, and 
do not influence our decision; we examine an amicus curiae brief solely for whatever aid it provides in analysing the legal questions before us. $(587 / 434$, n.16)

The massing of amici on each side does, however, allegorize the industrial and commercial interests at play in the case, and it would seem that the presentation of amicus curiae briefs works in part as a kind of judicial lobbying. Furthermore, the annotation on this judgment in the Lawyers' Edition suggests a consistent economic rationale for copyright decisions (as opposed to a basis purely in questions of right):

Viewing the Supreme Court's decisions as a whole, it seems that infringement questions dealing with 'new technology' are decided on the following basis: if the new technology cuts into the market and/or profits that the copyright holder enjoyed prior to the technological advance, then the 'use' or 'device' constitutes infringement; but, if the technological advance merely creates and services a 'new' market, which never belonged to the copyright holder, there is no infringement until Congress amends the Act to expressly say so. (961)

It is the fourth fair use criterion, requiring consideration of effects upon the potential value of copyrighted works, that is the crucial juridical determinant here. The language of the majority in applying this criterion is restrained and stays fairly rigorously within a juridical discourse; it is only in the ambiguity of the metaphor of a 'calculus of interests', and in its willingness to consider commercial arguments about the effect of timeshifting on audience structure, or about possible losses to advertisers, that the Court allows the economic rationale a discursive presence. The language of the dissent, by contrast, is consistently marked by an overdetermination of the juridical by the economic. This affects in particular its construction of fair use as involving a negative fee.

Consider this passage:

There is a crucial difference between the scholar and the ordinary user. When the ordinary user decides that the owner's price is too high, and foregoes use of the work, only the individual is the loser. When the scholar foregoes the use of a prior work, not only does his own work suffer, but the public is deprived of his contribution to knowledge. The scholar's work, in other words, produces external benefits from which everyone profits. In such a case, the fair use doctrine acts as a form of subsidy albeit at the first author's expense - to permit the second author to make limited use of the first author's work for the public good. (614/477-8)

Conversely, if the use is 'unproductive' in this sense, there is 'no need whatsoever to provide the ordinary user with a fair use subsidy at the author's expense' $(615 / 480)$. 
Here, intellectual property is thought of in purely negative terms, as a right of exclusion; and public access is thought of as a privilege conceded by the owner. Fair use is thus a 'subsidy' in so far as it is equivalent to a permission not to pay rent for the use of the work. The fundamental question of whether there should be any necessity for use to be forgone cannot be thought of within the framework of this imaginary market, since the market is conceived as an inexorable given rather than as a social construct, the mechanisms of which are relatively arbitrary, and which governmental and judicial intervention would be capable of modifying for social ends. In any case, the variables in this market are wrongly constructed: both the majority and the minority fail to consider the implications of the fact that (commercial) television programmes are not 'free' but are paid for by advertisers, and so, indirectly, by consumers who pay a 'tax' on advertised products (and this means that the technical question of the capacity of VTRs to erase advertisements is crucial to the question of the repetition of performances). ${ }^{5}$

In another passage, the dissent argues that 'from the Studios' perspective, the consequences of home VTR recording are the same as if a business had taped the Studios' works off the air, duplicated the tapes, and sold or rented them to members of the public for home viewing' (619/486). Here again, home taping can be thought of in terms of 'sale or rental' only on the assumption of a negative fee - that is, in relation to an imaginary market which would set a royalty for timeshifted use.

It is clear that in both cases, then, one of the functions the Court takes upon itself is that of regulation of the market in information. This is a function within the economic sphere, and it supposes particular normative models of market relations in accordance with which the Court fashions its decisions (but this is not to say that this fashioning is not equally in accordance with 'immanent' legal criteria).

The second form of overdetermination of the text by other discourses is one which both overlaps with and contradicts the first. It has to do with an understanding of the purpose of copyright legislation. The majority opinion explains it this way: the limited monopoly granted by copyright law 'is a means by which an important public purpose may be achieved. It is intended to motivate the creative activity of authors and inventors by the provision of a special reward, and to allow the public access to the products of their genius after the limited period of exclusive control has expired' (584/429). In support of this, it quotes the judge in United States v Paramount Pictures, Inc., who is in his turn quoting Chief Justice Hughes in Fox Film Corporation v Doyal: " " 'It is said that reward to the author or artist serves to induce release to the public of the products of his creative genius'"' (584/429); reward to the copyright owner is purely secondary to this end.

The ideology concerns creative individuals; the reality is that of an industrial mode of production of information, and of financial rewards controlled by corporations. The dissenting opinion repeats this ideological occlusion, although it is more explicit about the fact that it thinks of copyright 
in economic terms. Thus it argues that the doctrine of fair use 'must strike a balance between the dual risks created by the copyright system: on the one hand, that depriving authors of their monopoly will reduce their incentive to create, and, on the other, that granting authors a complete monopoly will reduce the creative ability of others' $(615 / 479)$. This balance is not one of rights but of economic consequences - and again it involves a particular normative model of the market; but the recognition of the role of economic considerations is nevertheless eroded by the persistence of the concept of individual creativity, in relation to which economic reward has a purely auxiliary function.

This humanist ideology constitutes the gist of the argument, citing the testimony of the Register of Copyrights in the 1975 House hearings, to the effect that a threat to the author's copyright is posed not just by exploitative commercial interests, but by

people with a sincere interest in the public welfare who fully recognize ... 'that the real heart of civilization ... owes its existence to the author'; ironically, in seeking to make the author's works widely available by freeing them from copyright restrictions, they fail to realize that they are whittling away the very thing that nourishes authorship in the first place. $(616 / 481$, n.34)

The 'creativity' of 'authors' is 'nurtured' by the desire for economic gain; this desire is conceived of as universal and as individual; and it is understood in complete abstraction from the industrial and commercial structures within which the production and ownership of books and films, of broadcast texts and computer software, of poems and of commercial directories and of racing guides, and of copies of copies of copies, take place.

What both the majority and the dissenting opinions in Sony have in common is their focus on a limited exemption from copyright; neither presumes a general freedom of information. In both cases the concept of the public domain is a purely residual one: rather than being itself a set of specific rights, the public domain is that space, that possibility of access, which is left over after all other rights have been defined and distributed. This approach is consistent with American doctrine, where the concept of public domain has never been that of a positively elaborated set of rights (cf. Lange 1981). It has had a shadowy legal presence through common-law principles such as fair use, through administrative measures such as freedom-of-information regulations or through statutory protection of free speech, but its lack of doctrinal specification leaves it vulnerable to erosion. Many jurists have noted the encroachment in recent years of property rights on areas that had previously been considered to be in the public domain. The development of privacy rights and rights of publicity protecting personal attributes is one example; the extension of copyright protection to genetic information is another. More generally, it seems clear, if 
paradoxical, that the proliferation of information and information technologies, including those that make possible the limitless reproduction of 'original' works, has been intimately bound up with the process of commodification of knowledge. What Locksley (1986) calls the 'library' model of knowledge - a model, we should remember, that flourished for little more than a century - is rapidly being displaced by a model of protection and for-profit exploitation. To say this is not to suggest that in some mythical past (the eighteenth century of the 'bourgeois public sphere', for example) knowledge in some way escaped regulation and restriction; on the contrary, the public domain, like the 'public good', can only ever be the fragile effect of complex institutional structures and regulative relations. It is, however, to make the qualitative judgement that knowledge in the age of its limitless reproduction is becoming not more free but less so.

University of Queensland

\section{Notes}

1 For a qualification of this statement, cf. Saunders, 1992.

2 Sony Corporation of America, et al. v University City Studios, et al. 464 US, 417, 78 L Ed 2d 574, 104 S Ct 774, reh den (US) $80 \mathrm{~L} \mathrm{Ed} \mathrm{2d} \mathrm{148,} 104$ S Ct 1619. Citations in the text refer first to the pagination of the Lawyers' Edition and (if at all) second to 464 US 417.

3 Cf. Hexner (1941: 58): 'The first constitution of a state establishing a legal system cannot and must not be linked with preceding legal rules. In this sense the first constitution must be regarded as a political fact. Such a political fact has to be conceived metajuridically'.

4 Morley and Silverstone (1990:44) have written interestingly about the ways in which the proliferation of broadcast channels, cable and satellite have fragmented the more ordered forms of experience associated with the regular broadcast schedule. They write that 'these new forms of communication may in fact play a significant part in deconstructing national cultures, and the interactive and "rescheduling" potentialities of video and other new communications technologies may disrupt our assumptions of any "necessary simultaneity" of social experience'.

5 Cf. Vernet (1990) and Chateau (1990).

\section{References}

Attali, Jacques (1985) Noise: The

Political Economy of Music, trans. B.

Massumi, Minneapolis: University of

Minnesota Press.

Chateau, Dominique (1990) 'L'effet

zapping', Communications 51.

Frow, John (1988) 'Repetition and

limitation: computer software and

copyright law', Screen 29(1).
Gaines, Jane (1991) Contested Culture:

The Image, the Voice, and the Law, University of North Carolina Press. Hexner, Erwin (1941) Studies in Legal Terminology, University of North Carolina Press.

Lange, David (1981) 'Recognizing the public domain', Law and Contemporary Problems 44(4). 
Lardner, James (1987) Fast Forward: Hollywood, the Fapanese, and the Onslaught of the VCR, New York: Norton.

Locksley, Gareth (1986) 'Information technology and capitalist development', Capital and Class 27.

Lury, Celia (1993) Cultural Rights:

Technology, Legality and Personality, London: Routledge.

Marlow, Eugene and Secunda, Eugene (1991) Shifting Time and Space: The Story of Videotape, New York: Praeger.
Morley, David and Silverstone, Roger (1990) 'Domestic communication technologies and meanings', Media, Culture and Society 12(1).

Pêcheux, Michel (1982) Language, Semantics and Ideology, trans. H. Nagpal, Basingstoke: Macmillan.

Saunders, David (1992) Authorship and Copyright, London: Routledge. Vernet, Marc (1990) 'Incertain zapping', Communications 51. 


\section{University Library}

\section{- M M I N E R VA A gateway to Melbourne's research publications}

Minerva Access is the Institutional Repository of The University of Melbourne

Author/s:

Frow, John A.

Title:

Timeshift: technologies of reproduction and intellectual property

Date:

1994

Citation:

Frow, J. A. (1994) Timeshift: Technologies of Reproduction and Intellectual Property, in Economy and Society, 23(3):pp 291-304.

Publication Status:

Published

Persistent Link:

http://hdl.handle.net/11343/34475 